Received 23.10.2017 Reviewed 25.10.2017 Accepted 16.11.2017

A - study design

B - data collection

C - statistical analysis

D - data interpretation

$\mathbf{E}$ - manuscript preparation

F - literature search

\title{
The variability of pollution load of organic, biogenic and chromium ions in wastewater inflow to the treatment plant in Nowy Targ
}

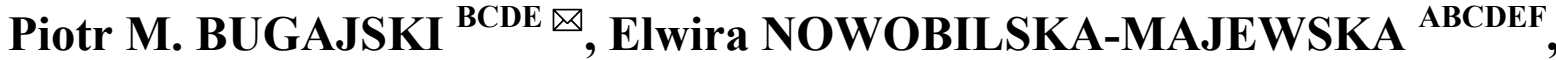 \\ Karolina KUREK ${ }^{\text {BCD }}$
}

\begin{abstract}
University of Agriculture in Krakow, Faculty of Environmental Engineering and Land Surveying, Department of Sanitary Engineering and Water Management, al. Mickiewicza 24/28, 30-059 Kraków, Poland; e-mail: p.bugajski@ur.krakow.pl, elwiranowmaj@gmail.com, karolina.kurek@urk.edu.pl
\end{abstract}

For citation: Bugajski P.M., Nowobilska-Majewska E., Kurek K. 2017. The variability of pollution load of organic, biogenic and chromium ions in wastewater inflow to the treatment plant in Nowy Targ. Journal of Water and Land Development. No. 35 p. 11-17. DOI: 10.1515/jwld-2017-0063.

\begin{abstract}
The aim of the study was to analyze the mean daily wastewater load from the corporate wastewater treatment plant in Nowy Targ. The study analyzed the wastewater load expressed by $\mathrm{BOD}_{5}, \mathrm{COD}$, total nitrogen $\left(\mathrm{N}_{\text {tot }}\right)$, total phosphorus $\left(\mathrm{P}_{\text {tot }}\right)$ and chromium ions $(\mathrm{Cr})$. The study was conducted from 2006 to 2016 , in which 591 samples of raw wastewater were collected and analyzed in a control well before the treatment plant with a mean of 4 times a month. The scope of research in the analytical part covered the variability of wastewater loads in individual years and determined the characteristic values of mean daily load in particular months. Mean daily wastewater load for $\mathrm{BOD}_{5}-7053 \mathrm{~kg} \cdot \mathrm{d}^{-1}$ for COD $-23437 \mathrm{~kg} \cdot \mathrm{d}^{-1}$ for total nitrogen $-1464 \mathrm{~kg} \cdot \mathrm{d}^{-1}$ for total phosphorus $-197 \mathrm{~kg} \cdot \mathrm{d}^{-1}$ and for chromium ions $-129 \mathrm{~kg} \cdot \mathrm{d}^{-1}$. For each of the analyzed index, it was found that in the each months mean daily wastewater load in raw wastewater is variable. In the analyzed period the mean daily discharged wastewater oscillated within $13924 \mathrm{~m}^{3} \cdot \mathrm{d}^{-1}$, which accounted for about $66 \%$ of the projected load.
\end{abstract}

Key words: chromium ions, organic and biogenic pollution, pollution load, wastewater

\section{INTRODUCTION}

The construction of a new or the modernization of an existing sewage treatment plant should be preceded by detailed and precise research concerning the amount of inflow wastewater and the load of pollutants contained in this wastewater [BARTOSZEWSKI 2000]. The mistakes made at the project stage in terms of determining the amount of wastewater and loads of particular pollutants will result in malfunctions in the exploitation of the facility and consequently the reduced efficiency of sewage treatment. The data (adopted to the design of wastewater treatment technology) commonly referred to as typical data, which are often taken from literature, may be irrelevant to the actual values observed in a certain case [KACZOR 2009; KACZOR, PAWEŁEK 2002; WoźNIAK-VeCCHIE, BugajSKi 2011]. In Poland, the majority of the currently used and newly designed sewage treatment plants are based on the technology of activated sludge [PAWEŁEK 2016; PAWESKA, BAWIEC 2017]. The method based on activated sludge microorganisms is sensitive both to the variability of the amount of wastewater and the variability of the load of pollutants contained in this wastewater [BARNARD 2000, JÓźWIAKOWSKI et al. 2017; SIWIEC et al. 2012; TAKÁCS 2008]. A frequently hydraulic problem of wastewater treatment plant is the periodic quantity excess of sewage on the inflow. Mostly the reasons of this problem are illegal discharge of rainwater to the 
sewage system. The larger inflow sewage into treatment plant than assumptions in the project is the reason of reduce retention time of sewage in technological devices, thereby reduce sedimentation and flotation time. It also reason of reduce time which is necessary to decomposition of organic and inorganic pollutants in biological reactor [KACZOR 2012; KACZOR et al. 2017]. The only possibility to prevent this type of problems (discharge of rainwater) is monitoring of sewage system and elimination of illegal connections to sewage system [KACZOR et al. 2013]. Furthermore, there are many factors that have an impact on the proper metabolism of activated sludge microorganisms. These factors include the type of chemicals, temperature, $\mathrm{pH}$, content of oxygen and the amount of a pollutant load in activated sludge [BUGAJSKI 2011; FELICJANIAK, URBANIAK 2010; WAŁĘGA et al. 2014]. An additional factor affecting the type of technology of its modernization is the presence of an industrial wastewater or/and precipitation water additive in household wastewater [BUGAJSKI, SATORA 2011; BUGAJSKI et al. 2017]. Industrial wastewater is characterized by a definitely other type and amount of pollutant loads than domestic wastewater [KRZANOWSKI et al. 2008; MASSÉ, MASSE 2000; NOWOBILSKA-LUBERDA et al. 2013]. Attendance of industrial wastewater in domestic sewage inflow into the treatment plant, can be the reason of interference in purification process, and also can lead to deterioration of the natural environment [RATAJCZYK et al. 2015; ŚWIERK 2016]. Such an example can be the sewage system in Nowy Targ, where there is the tanning industry. Post-production wastewater from this industry contains high amounts of chromium ions [PRZYWARA 2017]. This type of sewage cannot be directly introduced into the sewage system without prior pretreatment, but many factories illegally discharge it directly into the sewage system. It is difficult or even impossible to completely eliminate this phenomenon. Therefore, it is important to accurately diagnose the charge of chromium ions in the incoming wastewater and consider these quantities in the modernization of wastewater treatment plant [MENDRYCKA, STAWARZ 2012].

\section{MATERIAL AND METHODS}

The aim of this study is to analyse the size and variability of the average daily loads of pollutants flowing into wastewater at the collective sewage treatment plant in Nowy Targ. The work analysed organic pollutants expressed by $\mathrm{COD}$ and $\mathrm{BOD}_{5}$ ratios, biogenic impurities expressed by the following indicators: total nitrogen $\left(\mathrm{N}_{\text {tot }}\right)$ and total phosphorus $\left(\mathrm{P}_{\text {tot }}\right)$, as well as the load of chromium ions $(\mathrm{Cr})$. The researches were carried out in the years 2006-2016. During this period, 591 samples of raw wastewater were collected in the control-measurement drain located before the sewage treatment plant. Moreover, these samples were subjected to the physical-chemical analysis in accordance with reference methods set out in the applicable legal acts.

- BOD $_{5}$ - PN-EN1899-1:2002;PNEN25814:1999,

- COD $_{\text {cr }}$ PN-ISO 15705:2005,

- total nitrogen - KJ-I-5.4-186,

- total phosphorus - PN-EN ISO6878:2006 + Ap1:2010 + Ap2010,

- chromium - EN ISO11083 DIN 38405-D24.

The average frequency for collection and analysis of wastewater was 4 times a month. Raw sewage samples were taken from inflow channel by autosampler, which was programmed in relation to the flow rate of the sewage.

The scope of researches in the analytical part covered the variability of pollutants in particular years. Moreover, the study presents characteristic values of an average daily load in individual months in the examined multiannual period. The results of the analysis contribute to determine the duration of nitrification and denitrification processes in the modelling of the technology of sequential reactors (SBR systems) in the sewage treatment plant in Nowy Targ in the aspect of their modernization in order to improve the efficiency of pollution removal. The daily load of particular types of pollutants was determined on the basis of the following equation (1):

$$
t_{x}=S_{x} Q_{s r . d} / 1000
$$

where: $E_{x}$ - daily load of pollutant index $\left(\mathrm{kg} \cdot \mathrm{d}^{-1}\right), S_{x}-$ concentration of pollutant index $\left(\mathrm{g} \cdot \mathrm{m}^{-3}\right), Q_{\text {sr.d. }}-$ average daily inflow of wastewater $\left(\mathrm{m}^{3} \cdot \mathrm{d}^{-1}\right)$.

\section{Characteristics of the sewage system}

The sewage system in Nowy Targ has a length of $86.9 \mathrm{~km}$, The system is divided into two water catchment areas. The first one includes Szaflary Axle, the second one Ludźmierz Axle. The sanitary network is made of stoneware pipes (about 40\%), concrete (about $10 \%$ ) and wipro (about 10\%) with diameters from 200 to $400 \mathrm{~mm}$. At present the sewage system is based on new technologies; mainly from PVC pipes as well as from new generation stoneware as well as composite pipes made of fiberglass reinforced plastic. The sewage from the sanitary sewage network to the sewage treatment plant is drained by the gravity method and in a small part with four sewage pumping stations. Today, the sewage system is used by 47537 residents. Additionally, 60 legally operated furrier's production facility are connected to the sewage system. They discharge industrial wastewater. Household and industrial effluent wastewater flow into the collective mechanical and biological sewage treatment plant with the designed flow capacity $Q_{\text {sr.d. }}=21000 \mathrm{~m}^{3} \cdot \mathrm{d}^{-1}$ and PE (population equivalent) $=116000$. In the sanitary sewage system which was analyzed, also exist problem with illegal discharge of rainwater to the sewage system. Based on the information from the employees of the wastewater treatment plant, it was found that rainwater is $12 \%$ of total amount of wastewater. 


\section{RESULTS}

The analysis of sizes of individual loads for the determined indicators was based on the knowledge of the concentration of a certain parameter in wastewater inflows and the amount of raw wastewater inflows on the day of collection of the wastewater sample. The analysis of the size of loads in wastewater that flow into the sewage treatment plant was developed in two stages. The first stage enabled to determine the size and variability for loads of the selected parameters in individual years in the 11-year study period. The second stage helped to obtain characteristic values in individual months in the multiannual period.

In the period from 2006 to 2016, the average daily flow of wastewater to the above-mentioned sewage treatment plant oscillated at a level of $13924.6 \mathrm{~m}^{3} \cdot \mathrm{d}^{-1}$ and this inflow was lower by $33.7 \%$ than the projected value. Therefore, the facility was hydraulically under-loaded in the research period. However, it should be noted that in the studied years, the average daily inflow of wastewater was variable and ranged from the minimum inflow that occurred in 2011 and it amounted to (average) $12345,6 \mathrm{~m}^{3} \cdot \mathrm{d}^{-1}$ to the maximum in $2006\left(17099,6 \mathrm{~m}^{3} \cdot \mathrm{d}^{-1}\right)$. In the last 3 years of observation, the average daily inflow of wastewater has stabilized at the level of approx. $13700 \mathrm{~m}^{3} \cdot \mathrm{d}^{-1}$ and it is considered as reliable. The daily irregularity of inflowing wastewater mainly results from the fact of inflow of accidental water, i.e. rainwater that flows into roof gutters from the sanitary sewage system (illegally connected to the system). Currently, the monitoring of the sewage network is carried out - in order to detect and eliminate this type of connections, because this increases the costs of wastewater treatment.

In the examined period, the daily load of $\mathrm{BOD}_{5}$ in raw wastewater oscillated in the range from 5024 to $8332 \mathrm{~kg} \cdot \mathrm{d}^{-1}$. The average daily load of $\mathrm{BOD}_{5}$ was $7053 \mathrm{~kg} \cdot \mathrm{d}^{-1}$, while the median was $7146 \mathrm{~kg} \cdot \mathrm{d}^{-1}$. Therefore, it can be assumed that in $1 \mathrm{~m}^{3}$ of wastewater that flow in the sewage treatment plant, there is about $0.51 \mathrm{~kg}$ of $\mathrm{BOD}_{5}$. In the case of the second indicator determining the size of organic pollutions (in the form of COD), large fluctuations of the average daily load of these parameters during the test period were registered. These fluctuations ranged from 15516 to $29060 \mathrm{~kg} \cdot \mathrm{d}^{-1}$. During the whole study period, the average daily load of COD was $23437 \mathrm{~kg} \cdot \mathrm{d}^{-}$ ${ }^{1}$, while the median was $23391 \mathrm{~kg} \cdot \mathrm{d}^{-1}$. On average, in $1 \mathrm{~m}^{3}$ of wastewater there was almost $1.71 \mathrm{~kg}$ of COD. The amounts of organic pollution loads presented in parameters $\mathrm{BOD}_{5}$ and $\mathrm{COD}$ in wastewater inflows in the multiannual period 2006-2016 were presented in Figure 1.

The average daily total nitrogen load in inflow wastewater to the analysed sewage treatment plant was $1464 \mathrm{~kg} \cdot \mathrm{d}^{-1}$, while the median was $1261 \mathrm{~kg} \cdot \mathrm{d}^{-1}$. In the case of the first of the analysed biogenic indicators - total nitrogen, a large variation in the load of this parameter in wastewater inflows in individuals

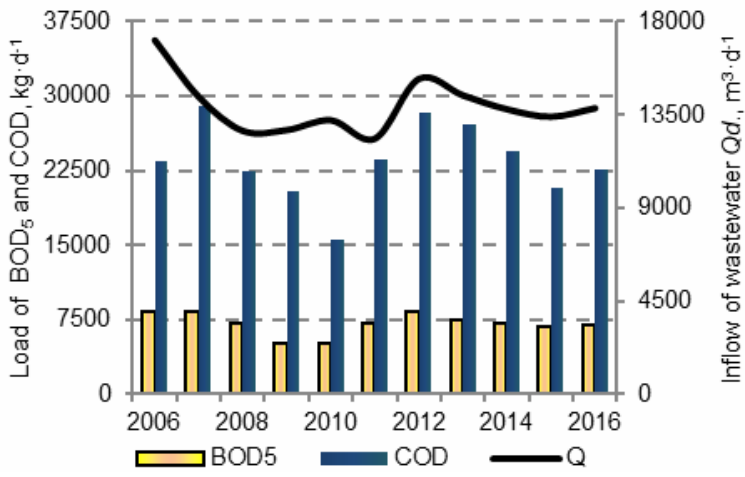

Fig. 1. Size of the average daily load of $\mathrm{BOD}_{5}$ and $\mathrm{COD}$ and the volume of raw wastewater in 2006-2016; source: own study

study years was observed. The highest average daily total nitrogen load was recorded in 2006 and it amounted to $2792 \mathrm{~kg} \cdot \mathrm{d}^{-1}$, while the smallest average daily load was recorded in 2010 and it amounted to $776 \mathrm{~kg} \cdot \mathrm{d}^{-1}$. Taking into account the average load from all years of observation, it was found that in $1 \mathrm{~m}^{3}$ of raw wastewater there is nearby $0.11 \mathrm{~kg}$ of total nitrogen. In the case of the second biogenic parametertotal phosphorus, the highest average daily load of this parameter was recorded in 2013 and it amounted to $313 \mathrm{~kg} \cdot \mathrm{d}^{-1}$, while the lowest load was recorded in 2009 and it amounted to $41 \mathrm{~kg} \cdot \mathrm{d}^{-1}$. The average daily total phosphorus load in the examined period was 197 $\mathrm{kg} \cdot \mathrm{d}^{-1}$ and the median was exactly at the same level $197 \mathrm{~kg} \cdot \mathrm{d}^{-1}$. Bearing in mind the average daily inflow of wastewater and the average daily total phosphorus load, it was stated that in $1 \mathrm{~m}^{3}$ of wastewater there is approx. $0.014 \mathrm{~kg}$ of total phosphorus. The quantities of biogenic pollution loads expressed by the parameters of total nitrogen and total phosphorus in wastewater inflows in the multiannual period 2006-2016 were presented in Figure 2. The load variability of these two indicators in individual years does not always correlate with the amount of wastewater inflowing to the treatment plant. This can be seen in the example of year 2009 and 2010. In these years, we have seen an increase in precipitation water into the sewage system, which contains lower concentrations of biological compounds. So in the same amount of sewage

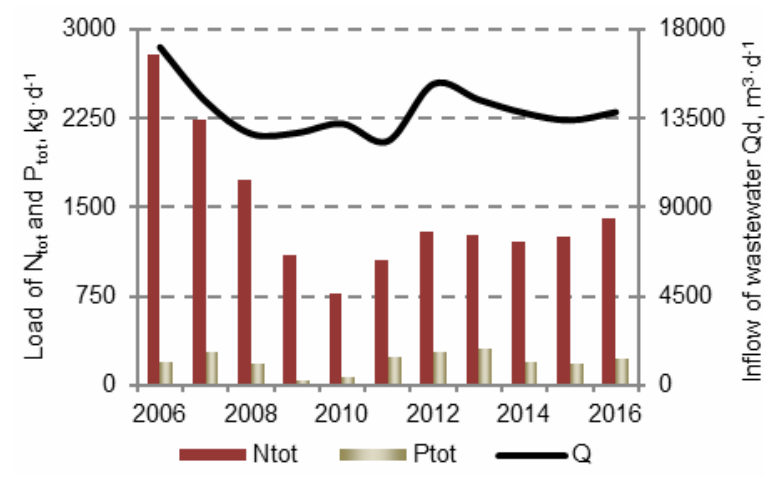

Fig. 2. Size of average daily load of $\mathrm{N}_{\text {tot. }}$ and $\mathrm{P}_{\text {tot. }}$ and volume of wastewater in 2006-2016; source: own study 


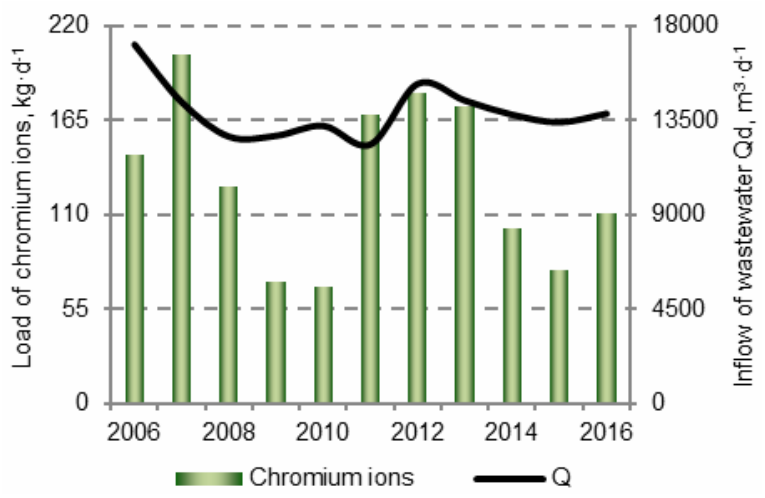

Fig. 3. Size of average daily load of chromium ions and volume of wastewater in 2006-2016; source: own study

was the smaller load of these parameters. The same situation was also observed with respect to chromium ions (Fig. 3.)

The average daily load of chromium ions in raw wastewater over the 11-year period was $129 \mathrm{~kg} \cdot \mathrm{d}^{-1}$, while the median was $126 \mathrm{~kg} \cdot \mathrm{d}^{-1}$. During the study period, there were large variations concerning the load of chromium in wastewater inflows in particular years. The smallest average daily load of chromium in wastewater inflows was recorded in 2010 and it was nearly $68 \mathrm{~kg} \cdot \mathrm{d}^{-1}$, while the largest load of this parameter was recorded in 2007 and it amounted to 203 $\mathrm{kg} \cdot \mathrm{d}^{-1}$. With respect to the average daily flow of wastewater at the level of $13700 \mathrm{~m}^{3} \cdot \mathrm{d}^{-1}$, it was found that in $1 \mathrm{~m}^{3}$ of wastewater there is almost $0.01 \mathrm{~kg}$ of chromium compounds. The amount of chromium loads floating in the multiannual period 2006-2016 was shown in Figure 3.

The second part of the analysis discussed the characteristics of pollutant loads observed in wastewater in particular months in multiannual period 2006-2016. This part of the analysis was carried out taking into account all the loads that occurred in individual months on the year in the 11-year study period. In the case of $\mathrm{BOD}_{5}$ load, the highest average daily size of the load was recorded in February and it amounted to $8375 \mathrm{~kg} \cdot \mathrm{d}^{-1}$, while the lowest size of the load was recorded in April - its average level was $6096 \mathrm{~kg} \cdot \mathrm{d}^{-1}$. The difference between minimum and maximum size of $\mathrm{BOD}_{5}$ load was $2279 \mathrm{~kg} \cdot \mathrm{d}^{-1}$. In comparison to the average size of $\mathrm{BOD}_{5}$ load, which was in wastewater throughout the study period, the maximum size was $10 \%$ higher than the average size, and the minimum size was $14 \%$ lower than the average size. In each monthly period, large variations of $\mathrm{BOD}_{5}$ load in raw wastewater were observed. The highest differences between the minimum and maximum load of this parameter were stated in months: February and June, while the lowest differences occurred in months: August and September. The highest $\mathrm{BOD}_{5}$ load recorded during the study period was at the level of $27390 \mathrm{~kg} \cdot \mathrm{d}^{-1}$. This means that in $1 \mathrm{~m}^{3}$ of wastewater, there is almost $2 \mathrm{~kg}$ of $\mathrm{BOD}_{5}$. The characteristic sizes of $\mathrm{BOD}_{5}$ load on a monthly basis are presented in Figure 4.

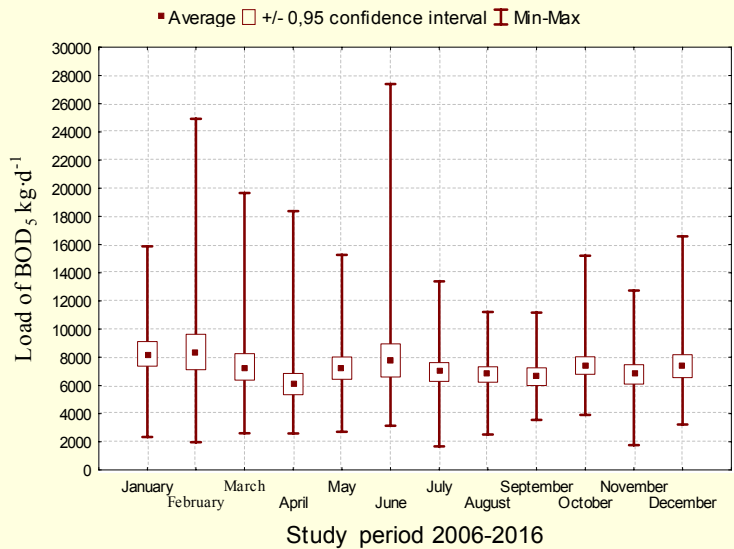

Fig. 4. The characteristic sizes of $\mathrm{BOD}_{5}$ load on a monthly basis in the period 2006-2016; source: own study

By analysing the average daily COD load, it was found that the highest average daily load occurred in August $-26083 \mathrm{~kg} \cdot \mathrm{d}^{-1}$, while the lowest in April $20270 \mathrm{~kg} \cdot \mathrm{d}^{-1}$. The difference between the minimum and maximum value of COD load was $5813 \mathrm{~kg} \cdot \mathrm{d}^{-1}$. By comparing the maximum and minimum load to the average size of COD load (observed in wastewater over the entire study period), it was found that the maximum size was $11 \%$ higher than the average size, and the minimum size was $13.5 \%$ lower than the average size. The highest differences between the minimum and maximum value were observed in January and August, while the smallest differences were determined in May and September. The maximum value of COD load was recorded in August at the level of $72658 \mathrm{~kg} \cdot \mathrm{d}^{-1}$. This means that on that day, in $1 \mathrm{~m}^{3}$ of raw wastewater there was $5.3 \mathrm{~kg}$ of COD. The characteristic sizes of COD load on a monthly basis are shown in Figure 5.

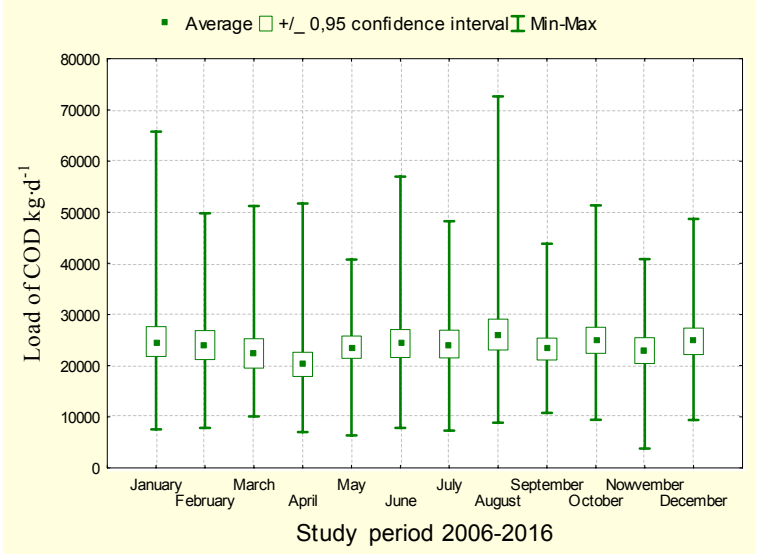

Fig. 5. The characteristic sizes of COD load on a monthly basis in the period 2006-2016; source: own study

By analysing the average daily total nitrogen load in wastewater inflows, it was found that the highest value occurred in February $-1956 \mathrm{~kg} \cdot \mathrm{d}^{-1}$ and the lowest in June $-1363 \mathrm{~kg} \cdot \mathrm{d}^{-1}$. The difference between these sizes of load was $593 \mathrm{~kg} \cdot \mathrm{d}^{-1}$. By comparing the 
maximum and minimum load to the average size of total nitrogen load observed in wastewater inflows, it was stated that the maximum size was $33.5 \%$ higher than the average size and the minimum size was $7 \%$ lower than the average size. Similarly as in the case of organic indicators, with respect to the load of total nitrogen, the values of $700-800 \mathrm{~kg}$ of nitrogen in a daily period were observed. The maximum load of total nitrogen was recorded in September at the level of $7934 \mathrm{~kg} \cdot \mathrm{d}^{-1}$, indicating that on this day there was $0.57 \mathrm{~kg}$ of total nitrogen in $1 \mathrm{~m}^{3}$ of wastewater. The characteristic sizes of total nitrogen load on a monthly basis are shown in Figure 6.

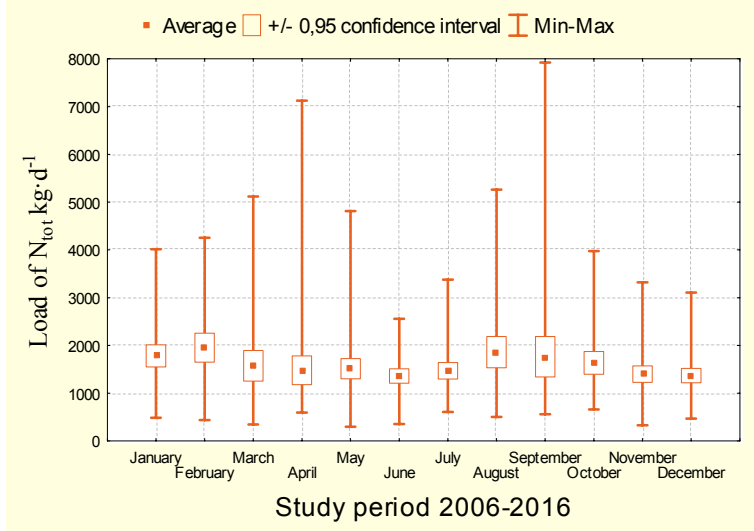

Fig. 6. The characteristic sizes of total nitrogen load on a monthly basis in the period 2006-2016; source: own study

The second biogenic indicator, i.e. the average daily load of total phosphorus, was characterized by a variability from the maximum value that occurred in August at the level of $237 \mathrm{~kg} \cdot \mathrm{d}^{-1}$ to the lowest value of $157 \mathrm{~kg} \cdot \mathrm{d}^{-1}$ observed in April. The difference between the maximum and minimum load was $80 \mathrm{~kg} \cdot \mathrm{d}^{-1}$. The maximum load was $20.3 \%$ higher than the average load, while the minimum load of total phosphorus was $20.4 \%$ lower than the average load. In this case, wastewater flows with high average daily load of total phosphorus were recorded. The maximum average daily load of this parameter was recorded in June and it was at the level of $596 \mathrm{~kg} \cdot \mathrm{d}^{-1}$. This means that in $1 \mathrm{~m}^{3}$ of raw wastewater, there was $0.04 \mathrm{~kg}$ of total phosphorus. The characteristic values for the load of total phosphorus on a monthly basis are presented in Figure 7.

The average daily load of chromium ions ranged from $104 \mathrm{~kg} \cdot \mathrm{d}^{-1}$ in April to $163 \mathrm{~kg} \cdot \mathrm{d}^{-1}$ in December. The difference between the minimum and maximum load is $59 \mathrm{~kg} \cdot \mathrm{d}^{-1}$. The maximum load of this parameter was $26.3 \%$ higher than the average load, while the minimum load was $19.4 \%$ lower than the average load. In the case of the average daily load of chromium ions, the maximum volume was recorded in March and it amounted to $994 \mathrm{~kg} \cdot \mathrm{d}^{-1}$. On the day, when this maximum load appeared, it was stated that $0.07 \mathrm{~kg}$ of chromium ions was in $1 \mathrm{~m}^{3}$ of raw wastewater. The characteristic values of chromium ion load on a monthly basis are shown in Figure 8.

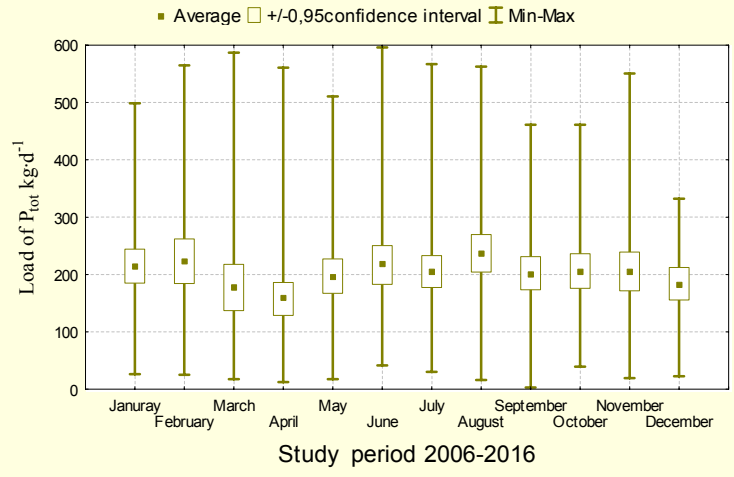

Fig. 7. The characteristic sizes of total phosphorus load on a monthly basis in the period 2006-2016; source: own study

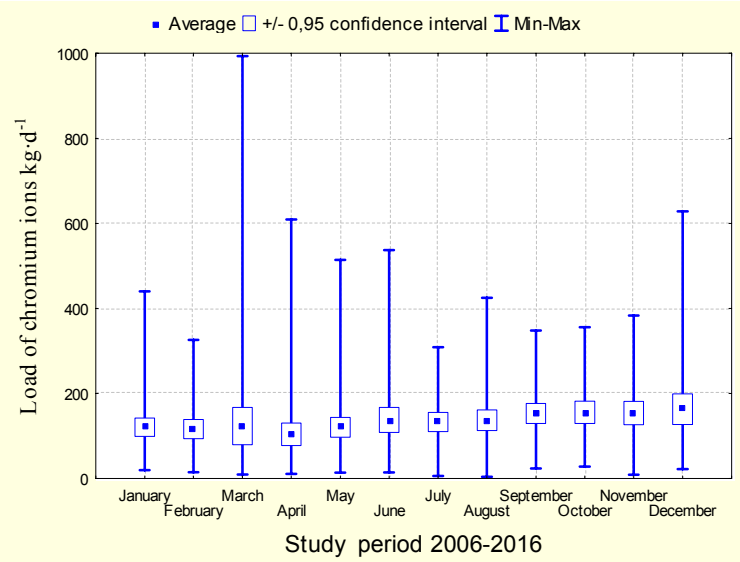

Fig. 8. The characteristic sizes of chromium ions load on a monthly basis in the period 2006-2016; source: own study

In summarizing this part of the analysis, in relation to all analysed indicators of pollutions, large fluctuations of pollution loads in raw wastewater were found in practically each monthly period. In the analysed period, the average daily load of organic pollutants, determined by $\mathrm{BOD}_{5}$ and $\mathrm{COD}$ indicators, amounted to 7053 and $23437 \mathrm{~kg} \cdot \mathrm{d}^{-1}$, respectively. On a monthly basis, the average daily load of $\mathrm{BOD}_{5}$ ranged from $6096 \mathrm{~kg} \cdot \mathrm{d}^{-1}$ in April to $8375 \mathrm{~kg} \cdot \mathrm{d}^{-1}$ in February. On a monthly basis, the average daily load of COD ranged from $15516 \mathrm{~kg} \cdot \mathrm{d}^{-1}$ in April to 29060 $\mathrm{kg} \cdot \mathrm{d}^{-1}$ in August. In the 11-year study period, the average daily loads of biogenic pollutions (expressed by indicators of total nitrogen and total phosphorus) amounted to $1464 \mathrm{~kg} \cdot \mathrm{d}^{-1}$ for nitrogen and $197 \mathrm{~kg} \cdot \mathrm{d}^{-1}$ for phosphorus. In the examined period (in individual months), the fluctuations of the load for both biogenic indicators were stated. For total nitrogen from 1363 $\mathrm{kg} \cdot \mathrm{d}^{-1}$ (June) to $1956 \mathrm{~kg} \cdot \mathrm{d}^{-1}$ (February) and for total phosphorus from $157 \mathrm{~kg} \cdot \mathrm{d}^{-1}$ (April) to $237 \mathrm{~kg} \cdot \mathrm{d}^{-1}$ (August). In the examined period, the average daily load of chromium ions in raw wastewater was at the level of $129 \mathrm{~kg} \cdot \mathrm{d}^{-1}$, with fluctuations in particular months from $104 \mathrm{~kg} \cdot \mathrm{d}^{-1}$ in April to $163 \mathrm{~kg} \cdot \mathrm{d}^{-1}$ in December. 


\section{CONCLUSIONS}

During the period from 2006 to 2016 though a high variability in the amount of inflowing sewage, the treatment plant was daily hydraulically under loaded on average by approximately $30 \%$ relative to the designed capacity. Therefore, it is possible to build an extension of the sewage system in the municipality or neighboring towns so as to increase the amount of inflowing wastewater. It is possible to increase the amount of wastewater by transporting them from non-channelized areas by cesspool emptier. Bearing in mind the large fluctuations in daily pollution loads in wastewater, the part of biological function of the treatment plant should be optimized again. It is possible to determine the cycle length and length of each phase of the SBR reactor cycle use the models for the sewage treatment plant design having detailed data. Action should also be taken in order to modernize the technological process of treating wastewater from chromium compounds. However, in the first place it is necessary to eliminate the excessive inflow of chromium compounds and other pollutants inflowing in sewage system and eliminate the effect or eliminate illegal wastewater inflows into the sewage network. In addition, it is necessary to limit the inflow of rain water by removing the illegal connections of roof gutters to the sewage system. This will result in less unevenness of incoming sewage and less unevenness of pollutants contained in them. The proposed measures will also have a measurable financial impact, as the elimination of excessive inflows of industrial effluents and precipitation will reduce the cost of wastewater treatment.

\section{Acknowledgement}

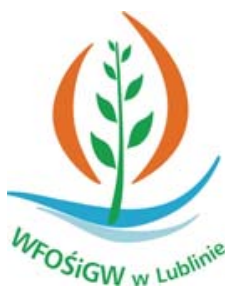

Dofinansowano ze środków

Wojewódzkiego Funduszu Ochrony Środowiska

i Gospodarki Wodnej w Lublinie Cofinanced by Voivodeship Fund

for Environmental Protection and Water Management in Lublin

\section{REFERENCES}

BARNARD J.L. 2000. Projektowanie oczyszczalni z osadem czynnym usuwających związki biogenne. W: Filozofia projektowania a eksploatacja oczyszczalni ścieków [Design of a treatment plant with activated sludge to remove biogenic compounds. In: Philosophy of design and operation of wastewater treatment plant]. Materiały seminarium szkoleniowego. LEM PROJEKT s.c. Kraków 28-29.06.2000 p. 13-60.

BARTOSZEWSKI K. 2000. Proces projektowania oczyszczalni - praktyka i problemy. W: Filozofia projektowania a eksploatacja oczyszczalni ścieków [The process of designing a treatment plant - practice and problems. In: Philosophy of design and operation of wastewater treatment plant]. Materiały seminarium szkoleniowego LEM PROJEKT s.c. Kraków 28-29.06.2000 p. 8-12.

BUGAJSKI P. 2011. Wpływ temperatury ścieków na wielkość wybranych wskaźników zanieczyszczeń z oczyszczalni działającej w układzie sekwencyjnym SBR [The effect of sewage temperature on values of the selected sewage pollution indexes for the sequential batch reactor (SBR) treatment plant]. Infrastruktura i Ekologia Terenów Wiejskich. Nr 2 p. 7-15.

BugajSki P., Kaczor G., Chmielowski K. 2017. Variable dynamics of sewage supply to wastewater treatment plant depending on the amount of precipitation water inflowing to sewerage network. Journal of Water and Land Development. No. 33 p. 57-63. DOI 10.1515/ jwld-2017-0019.

BUGAJSKi P., SATORA S. 2011. Wpływ zanieczyszczeń odprowadzanych z ubojni trzody chlewnej oraz masarni na jakość ścieków dopływających do oczyszczalni [Influence of pollutants disposed from the butchery of pigs and cutting plant on the quality of sewage flowing into the treatment plant]. Acta Scientiarum Polonorum Formatio Circumiectus. T. 10. Z. 2 p. 3-10.

FELICJANiAK B., URBANIAK M. 2010. Ocena efektywności biologicznego oczyszczania ścieków zawierających związki chromu za pomocą wskaźników tlenowych. Cz. I [Biological purification of sewage containing chromium compounds estimated by means of oxygen indicators. P. I]. Przegląd Włókienniczy - Włókno, Odzież, Skóra. Nr 6 p. 38-41.

JóźWIAKowski K., MARZEC M., FiedUREK J., KAMIŃSKA A., Gajewska M., Wojciechowska E., Shubiao W., Dach J., MarczuK A., KowalcZYK-Juśko A. 2017. Application of $\mathrm{H}_{2} \mathrm{O}_{2}$ to optimize of ammonium removal from domestic wastewater. Separation and Purification Technology. Vol. 173 p. 357-363.

KaCzOR G. 2009. Stężenia zanieczyszczeń w ściekach odprowadzanych $\mathrm{z}$ wiejskich systemów kanalizacyjnych województwa małopolskiego [Concentrations of the pollutants in the sewage drained from the rural sewerage systems in Lesser Poland voivodship]. Infrastruktura i Ekologia Terenów Wiejskich. Nr 9 p. 97-104.

KACZOR G. 2012. Wpływ wód infiltracyjnych i przypadkowych na funkcjonowanie małych systemów kanalizacyjnych [Effect of infiltration and inflow waters on the performance of small sewer systems]. Rozprawa habilitacyjna. Nr 372. Zeszyty Naukowe Uniwersytetu Rolniczego w Krakowie. Nr 495. ISSN 1899-3486 pp. 229.

Kaczor G., Bugajski P., Bergel T. 2013. Zastosowanie metody trójkąta do obliczenia objętości wód infiltracyjnych i przypadkowych w kanalizacji sanitarnej [Application of the triangle method for the calculation of the infiltration and inflow volume in a sanitary sewer system]. Infrastruktura i Ekologia Terenów Wiejskich. $\mathrm{Nr}$ 3/IV p. 263-274.

KaCZOR G., ChMIELOWsKi K., BUgajSKI P. 2017. Influence of extraneous waters on the quality and loads of pollutants in wastewater discharged into the treatment plant. Journal of Water and Land Development. No. 33 p. 7378. DOI 10.1515/jwld-2017-0021.

KACZOR G., PAweŁeK J. 2002. Pomiary natężenia przepływu ścieków w wybranych oczyszczalniach województwa małopolskiego [Measurement of wastewater inflow rates in selected wastewater treatment plants in Małopolskie voivodship]. Inżynieria Rolnicza 3(36) p. 239-251.

KrZANOWski S., WaŁęga A., PAŚmionKa I. 2008. Oczyszczanie ścieków $\mathrm{z}$ wybranych zakładów przemysłu spo- 
żywczego [Treatment of sewage from selected food manufacturing plants]. Infrastruktura i Ekologia Terenów Wiejskich. Nr 1. Ser. Monografia. Kraków. Komisja Technicznej Infrastruktury Wsi PAN, Katedra Technicznej Infrastruktury Wsi AR. ISSN $1732-5587$ pp. 89.

MASSÉ D. I., MASSE L. 2000. Treatment of slaughterhouse wastewater in anaerobic sequencing batch reactors. Canadian Agricultural Engineering. Vol. 42/3 p. 131-137.

MENDRYCKA M., STAWARZ M. 2012. Zastosowanie biopreparatu wspomagającego oczyszczanie ścieków garbarskich osadem czynnym. Inżynieria Ekologiczna. Nr 28 p. 43-56.

NowobilsKa-Luberda A., NowobilsKa E., SATORA S. 2013. Jony chromu w ściekach i osadach dennych Podhala [Chromium ions in wastewater and bottom sediments in the Podhale area]. Acta Scientiarum Polonorum Formatio Circumiectus. T. 12. Z. 2 p. 73-82.

PAWEŁEK J. 2016. Degree of development and functionality of the water supply and sewage systems in rural Poland. Barometr Regionalny. Nr 14(1) p. 141-149.

PAWĘSKA K., BAWIEC A. 2017. Activated sludge technology combined with hydroponic lagoon as a technology suitable for treatment of wastewater delivered by slurry tanks. Journal of Ecological Engineering. Vol. 18. Iss. 2 p. 29-37.

PRZYWARA L. 2017. Zastosowanie procesu Fentona do oczyszczania ścieków garbarskich [Application of Fen- ton's process for treatment of tannery wastewater]. Inżynieria Ekologiczna. Vol. 18. Nr 2 p. 117-122.

RATAJCZYK N., WOLAŃSKA-KAMIŃSKA A. 2015. Ochrona różnorodności biologicznej obszarów wiejskich w świetle zapisów gminnych programów ochrony środowiska [Biodiversity conservation in rural areas in view of the commune programmes of environmental protection]. Woda-Środowisko-Obszary Wiejskie. T. 15. Z. 3 (51) s. $113-125$.

Siwiec T., Kiedryńska L., Abramowicz K., Rewicka A. 2012. Analysis of chosen models describing the changes in $\mathrm{BOD}_{5}$ in sewages. Environment Protection Engineering. Vol. 3. No. 2 p. 61-76.

ŚWIERK W. 2016. Gospodarka wodno-ściekowa w gminie Raba Wyżna [Water and sewage management in the Raba Wyżna commune]. Woda-Środowisko-Obszary Wiejskie. T. 16. Z. 4 (56) s. 97-123.

TAKÁCS I. 2008. Experiments in Activated Sludge Modelling. PhD Thesis. Ghent University, Belgium pp. 267.

Walęga A., Cupak A., Pawelek J., Michalec B. 2014. Transformation of pollutants in the stormwater treatment process. Polish Journal of Environmental Studies. T. 23. Nr 3 p. 909-916.

Woźniak-Vecchie R., Bugajski P. 2011. Wyznaczanie obciążenia hydraulicznego modernizowanych systemów ściekowych [Determination of hydraulic load of modernized sewage systems]. Gaz, Woda i Technika Sanitarna. $\mathrm{Nr} 10$ p. $410-412$.

\section{Piotr M. BUGAJSKI, Elwira NOWOBILSKA-MAJEWSKA, Karolina KUREK}

\section{Zmienność ladunku zanieczyszczeń organicznych, biogennych oraz jonów chromu w ściekach dopływających do oczyszczalni w Nowym Targu}

\section{STRESZCZENIE}

Celem pracy jest analiza wartości średnich dobowych ładunków zanieczyszczeń dopływających w ściekach surowych do zbiorczej oczyszczalni w Nowym Targu. W pracy poddano analizie zanieczyszczenia wyrażone wskaźnikami $\mathrm{BZT}_{5}, \mathrm{ChZT}$, azotu ogólnego $\left(\mathrm{N}_{\mathrm{og}}\right)$, fosforu ogólnego $\left(\mathrm{P}_{\mathrm{og}}\right)$ oraz ładunkiem jonów chromu $(\mathrm{Cr})$. Badania prowadzono w okresie od 2006 do 2016 roku, w którym pobrano i poddano analizie 591 próbek ścieków surowych pobranych w studzience kontrolno-pomiarowej przed oczyszczalnią ze średnią częstością 4 razy w miesiącu. W części analitycznej zakresem badań objęto zmienność ładunków zanieczyszczeń w poszczególnych latach oraz określono charakterystyczne wartości średniego dobowego ładunku w poszczególnych miesiącach. Na podstawie przeprowadzonej analizy stwierdzono, że średni dobowy ładunek wyrażony BZT $_{5}$ wyniósł $7053 \mathrm{~kg} \cdot \mathrm{d}^{-1}, \mathrm{ChZT}-23437 \mathrm{~kg} \cdot \mathrm{d}^{-1}$, ładunek azotu ogólnego $-1464 \mathrm{~kg} \cdot \mathrm{d}^{-1}$, fosforu ogólnego $-197 \mathrm{~kg} \cdot \mathrm{d}^{-1} \mathrm{i}$ jonów chromu $-129 \mathrm{~kg} \cdot \mathrm{d}^{-1}$. W odniesieniu do każdego $\mathrm{z}$ analizowanych wskaźników stwierdzono, że w poszczególnych miesiącach średni dobowy ich ładunek w ściekach surowych jest zmienny. W analizowanym okresie średni dobowy dopływ ścieków oscylował w granicach $13924 \mathrm{~m}^{3} \cdot \mathrm{d}^{-1}$, co stanowiło około $66 \%$ obciążenia projektowanego.

Słowa kluczowe: jony chromu, ładunek zanieczyszczeń, ścieki, zanieczyszczenia biogenne, zanieczyszczenia organiczne 